Pak. j. sci. ind. res. Ser. B: biol. sci. 2021 64B(1) 81-86

\title{
Evaluation of Phyllanthus niruri L. from Malaysia for In-vitro Anti-Urolithiatic Properties by Different Solvent Extraction
}

\author{
Muhammad Tayyab Gul ${ }^{a, b}$, Norhayati Muhammad ${ }^{a, c *}$, Aslia Natasha Pauzi, \\ Mohd Fadzelly Abu Bakar, ${ }^{a, c}$ Balkis A. Talip ${ }^{\text {a,c }}$, Norazlin Abdullah ${ }^{\text {a,c }}$, Nur Fazira Abdul Rahim ${ }^{\text {a }}$, \\ Wan Nur Ain Syukriaha, Wan Marzuki ${ }^{a}$, Laily B. Din ${ }^{d}$ and Nazlina Ibrahim ${ }^{e}$. \\ ${ }^{a}$ Faculty of Applied Sciences and Technology, Universiti Tun Hussein Onn Malaysia (UTHM), \\ Pagoh Educational Hub, KM 1, Jalan Panchor, 84600 Muar, Johor, Malaysia \\ ${ }^{b}$ Faculty of Sciences and IT, Department of Chemical and Life Sciences, Qurtuba University of Science and \\ Information Technology, Peshawar, 25000, Pakistan \\ ${ }^{\mathrm{c}}$ Centre of Research for Sustainable Uses of Natural Resources (CoR-SUNR), Universiti Tun Hussein Onn Malaysia \\ (UTHM), Parit Raja, 86400 BatuPahat, Johor, Malaysia \\ ${ }^{\mathrm{d} S c h o o l ~ o f ~ C h e m i c a l ~ S c i e n c e s ~ a n d ~ F o o d ~ T e c h n o l o g y, ~ F a c u l t y ~ o f ~ S c i e n c e ~ a n d ~ T e c h n o l o g y, ~ U n i v e r s i t i ~ K e b a n g s a a n ~}$ \\ Malaysia, UKM Bangi 43600, Selangor D.E., Malaysia \\ ${ }^{\mathrm{e} S} \mathrm{School}$ of Biosciences and Biotechnology, Faculty of Science and Technology, Universiti Kebangsaan \\ Malaysia,UKM Bangi 43600, Selangor D.E., Malaysia
}

(received January 29, 2019; revised February $21^{\text {st }}$, 2019; accepted February 26, 2019)

\begin{abstract}
The Phyllanthus niruri is traditionally used for curing of kidney disorders and urinary stones in Malaysia. Hence the current work was aimed to evaluate the effect of different solvents extract (nhexane, ethyl acetate, methanol and water) of $P$. niruri for in vitro anti-urolithiatic properties in terms of inhibition activity on $\mathrm{CaOx}$ by using the rate of $\mathrm{CaOx}$ aggregation assay and dissolution of calcium oxalate $(\mathrm{CaOx})$ crystal by using titrimetry method. Cystone was used as positive control. The effects of cystone on slope of nucleation and aggregation as well as growth of $\mathrm{CaOx}$ were evaluated spectrophotometrically. The highest yield percentage of P.niruri was occupied by methanol (5.74 \%). The maximum inhibition against aggregation of $\mathrm{CaOx}$ crystals was also occupied by methanol $(66.67 \% \pm 1.61)$ and was comprised with alkaloid, steroid, terpenoid and tannin. Dissolution effect on calcium oxalate crystals indicates that the aqueous extracts of $P$. niruri was found to be more effective in dissolution of $\mathrm{CaOx}$ with $63.33 \% \pm$ 1.44. P. niruri significantly $(\mathrm{P}<0.05)$ inhibited the slope of nucleation and aggregation of $\mathrm{CaOx}$ crystallization, and reduced the crystal density. The results of the present study confirmed that $P$. niruri leaves can be used as remedial mediator for urolithiasis. However, further studies are required for isolation and identification of active constituents and their in-vivo confirmation.
\end{abstract}

Keyword: crystallization, dissolution, nucleation, P. niruri, anti-urolithiatic.

\section{Introduction}

Urolithiasis (from Greek oûron, " urine" and " stone") is a condition in which urinary calculus is formed or located anywhere in the urinary system or stones are formed in the kidney, bladder or ureters (Sharma et al., 2016). Different phytochemical events begins when the formation of kidney stone occurs like crystal nucleation, aggregation and end with retention within the urinary tract. Among the several types of kidney stones, the most common are calcium oxalate representing up to $80 \%$ of the analyzed stones. Calcium containing stones may be in the form of pure calcium oxalate $(50 \%)$ or calcium phosphate $(5 \%)$ and a mixture of both $(45 \%)$ followed by magnesium phosphate (15-20\%), uric acid

*Author for correspondence; E-mail: norhayatim@uthm.edu.my
(10\%) and cystine (1\%) (Singanallur et al., 2017). There are numerous methods had been reported to reduced or break the kidney stone. Traditional method of treatment is being reported from plants which are the most effective. Plants based on traditional knowledge can lead to the discovery of new drug and development of pharmacologically important products for human health care (Pauzi et al., 2018; Subramoniam, 2014). Almost, $80 \%$ of the world's population depends on the conventional medicine to cure most of their diseases (Gul et al., 2019; Kennedy, 2005). There is a number of plants which show promising anti-urolithiatic activity (Ram et al., 2015). Nowadays, these conventional remedies have become more popular because they are very efficient, have low side effects and reduce the reformation of stone. Usually, the decoction and infusion 
methods are used for extraction that is good way for extracting compounds of various plants.

Although water decoction method is still using, even this method abundantly used huge volume of water. Moreover, there are some dis-advantages associated with water such as water that gives an excellent growth for microbes and this condition leads to microbial contamination to the samples. Moreover, it will promote hydrolysis and enzymatic degradation in the plant sample (Azmir et al., 2013). In addition, water also attract to an extract along with polar compounds which could obstruct in the identification and quantification (Bandar et al., 2013). Furthermore, the large volume of hot water usually means that the plant sample will exposure to unpleasant taste for longer period (Bone and Mills, 2013).

The Phyllanthus niruri is the member of the family Euphorbiaceae, and because of its speciality commonly known as as "stone-breaker" (Kieley et al., 2008). The habitat of the plant is moist, shady places, rock and some time epiphytes. The morphology of the plants states that leaf blade rounded to complement the elongated egg and green fruit. It can grow up to $60 \mathrm{~cm}$. furthermore, the tastes of $P$. niruri is bitter, cool, and as an astringent (Dalimartha, 2008).

Wang et al. (1995) identified the bioactive compounds like alkaloids, coumarins flavonoids, lignans, polyphenols, saponins tannins and terpenoids from different parts of $P$. niruri. Furthermore, Bagalkotkar et al. (2006) stated that 50 different bio-active compounds were identified from the $P$. niruri, including flavonoids, alkaloids, triterpenes and lignans. This is the proved that this plant diverse photochemical contents in different experimental studies. Alkaloid and triterpenes reported by many research as inhibited the cytotoxicity activated by calcium oxalate (Malini et al., 2000). Therefore, the current study will focus on the analytical methodologies, which include the extraction and its application as anti-urolithiatic activity.

\section{Materials and Methods}

Sample collection. The grinded leaves of $P$. niruri were purchased from Seri Subah Agrofarm, Negeri Semblian, Malaysia.

Sample preparation. The grinded plant samples were kept in the room temperature and dry place to maintain them in dry condition. The moisture content of the samples were measured and maintained at consistently about not more than $10 \%$ (Azwanida, 2015). Cystone was used as positive control while, distilled water was used as negative control.

Extraction process. The extraction method was followed by Fermeglia (2008) with slight modification. The plant samples were extracted by unlike non-polar solvents to polar solvents that are $n$-hexane, ethyl acetate, methanol and water. The extraction method was maceration using. The experiment was carried out in three replicates. The following equation used to calculate extraction yield:

Total extract yield, $\mathrm{Y}(\%)=\frac{\text { Total mass of extraction }}{\text { Total mass of sample }} \times 100$

Phytochemicals analysis of the plant samples. Phytochemical analysis was performed by standard method followed by Tiwari et al. (2011). All extracts used in these assays were $1 \mathrm{mg} / \mathrm{mL}$ in concentration.

Evaluation of anti-urolithiatic properties (in-vitro). Inhibition activity of plant extracts against calcium oxalate (CaOx) crystal by aggregation assay. The aggregation assay was done followed by Hess et al. (2000) with slight modifications. In addition, the inhibition rates of $\mathrm{CaOx}$ aggregation by the extracts were compared with the standard drugs, Cystone. $\mathrm{CaOx}$ crystals solution was prepared by using $10 \mathrm{mM}$ calcium chloride dihydrate and $1.0 \mathrm{mM}$ sodium oxalate, containing $200 \mathrm{mM} \mathrm{NaCl}$ and $10 \mathrm{mM}$ sodium acetate trihydrate. All tests were conducted at $37^{\circ} \mathrm{C}$ and 5.7 $\mathrm{pH}$. For crystallization of $\mathrm{CaOx}, 25 \mathrm{~mL}$ of calcium oxalate solution was shifted to a beaker and placed in a constantly stirring hot plate magnetic stirrer. Next to it added $1 \mathrm{~mL}$ of plant extract $(1 \mathrm{mg} / \mathrm{mL}) /$ Cystone $(1$ $\mathrm{mg} / \mathrm{mL}$ )/distilled water. The formation of the turbidity results immediately after the addition of $25 \mathrm{~mL}$ of sodium oxalate solution. The measurement of turbidity formed in terms of absorbance at $620 \mathrm{~nm}$ in UV-Vis spectrophotometer. It was started continuously for ten minutes after the mixing of the chemicals. In fact, the turbidity of solution increased indicates the nucleation process, and then decreased after some time which indicates the aggregation process. This experiment was done in three replications. The percentage inhibition rate of $\mathrm{CaOx}$ aggregation was calculated according (Sharma et al., 2016).

Inhibition $\%=[1-(\mathrm{Si} / \mathrm{Sc})] \times 100$

where; 
$\mathrm{Sc}=$ slope of aggregation without inhibitor (negative control); $\mathrm{Si}=$ slope of aggregation in the presence of inhibitor (positive control/ plant extracts)

Estimation of calcium oxalate by titrimetry method. Calcium oxalate $(10 \mathrm{mg}$ ) and plant extract or Cystone $(100 \mathrm{mg}$ ) was weighed respectively, and packed together in the semi-permeable membrane and carefully sutured. Then, it was allowed to suspend in a conical flask containing $100 \mathrm{~mL}$ of $0.1 \mathrm{M}$ TRIS buffer. The conical flasks were kept at room temperature for seven to eight hours. The remaining contents in the semi-permeable membrane is transferred into a beaker. Next, $1 \mathrm{~N}$ sulphuric acid $(2 \mathrm{~mL})$ was added and titrated with $\mathrm{KMnO}_{4}$ until a light pink colour appeared (Dwivedi, 2016). Consequently, $1 \mathrm{~mL}$ of $0.9494 \mathrm{~N} \mathrm{KMnO}_{4}$ equivalents to $0.1898 \mathrm{mg}$ of calcium.

$\%$ dissolved of calcium $=[(\mathrm{C}-\mathrm{T}) / \mathrm{C}] \times 100$

where;

$\mathrm{C}=$ precipitate of calcium oxalate remained in control $(\mathrm{mg}) ; \mathrm{T}=$ precipitate of calcium oxalate remained when test solution was used (mg).

Statistical analysis. All the experiments were conducted in triplicate and the data were presented as mean values and standard deviation. One way ANOVA applied on data using IBM SPSS Statistics software (Version 20.0, USA) with the level of significant $\mathrm{P}<0.05$.

\section{Results and Discussion}

Yields of extraction. As shown in Table 1, the effect of different solvents were studied in terms of the extraction yield. The solvents were selected based on their polarities. Polarity of a solvent plays a considerable role in the extraction process (Ahmad et al., 2017).

Based on the result, the highest yield percentage of P.niruri was occupied by methanol $(5.74 \%)$ followed by water $(2.15 \%)$, ethyl acetate $(1.46 \%)$, and lastly nhexane $(0.98 \%)$.

Table 1. The percentage yield of herbal plant extracts

\begin{tabular}{lllll}
\hline \hline Herbal plant & $\begin{array}{l}\text { Type of } \\
\text { solvent }\end{array}$ & $\begin{array}{l}\text { Mass of } \\
\text { sample (g) }\end{array}$ & $\begin{array}{l}\text { Mass of } \\
\text { extract (g) }\end{array}$ & $\begin{array}{l}\text { Yields } \\
(\%)\end{array}$ \\
\hline $\begin{array}{l}\text { Phyllanthus } \\
\text { niruri }\end{array}$ & $n$-hexane & 50 & 0.49 & 0.98 \\
& & & & \\
& Ethyl acetate & 50 & 0.73 & 1.46 \\
& Methanol & 50 & 2.87 & 5.74 \\
& Aqueous & 50 & 1.08 & 2.16 \\
\hline \hline
\end{tabular}

Consequently, different solvents exhibited different yield percentage for each plant samples. The results revealed that solvents yield wide range of extraction (0.98 -5.74\%). Among all of the solvent used, methanol exhibited the highest percentage of yields at the maximum percentage of $5.74 \%$. This result was similar to Kotze et al. (2002) which reported that methanol shown to be the best extraction solvent for Combretum erythrophyllum as compared with other extraction solvents. Similar findings have been observed in other studies done by Suleiman et al. (2010) which reported that hexane extract was found to be the lowest amount of extract yielded from Kirkia wilmsii.

Phytochemical associated with anti-urolithiatic properties of plant extracts. The results of phytochemical screening in Table 2 revealed that the presence of alkaloid, steroid, terpenoid, tannin, and saponin in plant extracts. However, based on the result obtained, the amount of detectable phytochemicals in every solvent extract is different from each other. This might be due to the different polarity of solvents could selectively extracts different type of phytochemicals (Dailey and Vuong, 2015; KV et al., 2014; Chavan et al., 2013; Rebey et al., 2012). Different type of phytochemicals that are present in each extract might have some positive contribution to anti-urolithiatic effect against calcium oxalate crystals either in term of inhibition or dissolution properties.

Evaluation of anti-urolithiatic properties (in-vitro). Inhibiting effect of P. niruri on calcium oxalate crystals. The inhibition percentage of P.niruri extracts was shown in Table 3. The highest inhibition percentage of $P$. niruri extract against aggregation of $\mathrm{CaOx}$ crystals was occupied by methanol with percentage of $66.67 \% \pm$

Table 2. The amount of detectable phytochemical of $P$. niruri extract

\begin{tabular}{|c|c|c|c|c|c|}
\hline $\begin{array}{l}\text { Type of } \\
\text { solvent }\end{array}$ & Alkaloid & Steroid & Terpenoid & Tannin & Saponin \\
\hline$n$-Hexane & ++ & ++ & + & - & - \\
\hline $\begin{array}{l}\text { Ethyl } \\
\text { acetate }\end{array}$ & - & ++ & - & - & ++ \\
\hline Methanol & + & +++ & + & + & - \\
\hline Aqueous & - & + & - & + & ++ \\
\hline
\end{tabular}


1.61 and was comprised with alkaloid, steroid, terpenoid and tannin. The studies regarding the phytochemicals in P.niruri were proven by Calixto et al. (1998) and Narendra et al. (2012) which reported that many bioactive compound from this plant have been identified which includes alkaloids, tannin, steroids and triterpenes.

Meanwhile, the second highest percentage of inhibition was hexane extract with $53.68 \% \pm 2.11$ which also contain the same phytochemical with methanol extract but differ in detectable amount. Moreover, aqueous and ethyl acetate extract of P.niruri showed quite low inhibition activity compared to methanol $(29.12 \% \pm$ $1.22)$ and $n$-hexane $(18.95 \% \pm 1.06)$. The significant different $(\mathrm{P}>0.05)$ between these two values was probably due to the absence of alkaloid and terpenoid in both extracts.

Dissolution of calcium oxalate crystals by titrimetry assay. This study evaluates the anti-urolithiatic activity by dissolving the artificial $\mathrm{CaOx}$ packed in semi permeable egg with the help of different solvent extracts of $P$. niruri. The work was performed by using in-vitro anti-urolithiatic model for calculating percentage dissolution of $\mathrm{CaOx}$ crystals. The amount of $\mathrm{CaOx}$ dissolved was nominated as the indicator to evaluate anti-urolithiatic activity. The results for the dissolution percentage of $\mathrm{CaOx}$ by plant extracts and standard are shown in Table 4. The amount of $\mathrm{CaOx}$ dissolved with standard drug was $73.33 \% \pm 3.82$ which is the highest percentage as compared to plant extracts. Consequently, all extracts showed their ability to dissolve the amount of $\mathrm{CaOx}$ inthe range from $65.83 \%$ to $36.67 \%$.

Based on the phytochemical screening, the ability of dissolving activity of plant extract on $\mathrm{CaOx}$ crystals

Table 3. The percentage of inhibition on rate of $\mathrm{CaOx}$ aggregation by plant extract and standard drug, cystone.

\begin{tabular}{lll}
\hline \hline $\begin{array}{l}\text { Herbal plant/ } \\
\text { Standard drug }\end{array}$ & Type of solvent & $\begin{array}{l}\text { Inhibition } \\
\text { percentage }(\%) \\
\text { (Mean } \pm \text { Standard } \\
\text { Deviation) }\end{array}$ \\
\hline $\begin{array}{l}\text { Cystone } \\
\text { Phyllanthus niruri }\end{array}$ & - & $92.28 \pm 0.61 \mathrm{a}$ \\
& -hexane & $53.68 \pm 2.11 \mathrm{~d}$ \\
& Ethyl acetate & $18.95 \pm 1.06 \mathrm{~h}, \mathrm{i}$ \\
& Methanol & $66.67 \pm 1.61 \mathrm{c}$ \\
& Aqueous & $29.12 \pm 1.22 \mathrm{~g}$ \\
\hline \hline
\end{tabular}

$\overline{\mathrm{a}, \mathrm{b}, \mathrm{c}, \text {, Values designated with different alphabets are }}$ significantly different from each other.
Table 4. The percentage of dissolution on $\mathrm{CaOx}$ crystals by plant extract and standard drugs, cystone.

\begin{tabular}{lll}
\hline \hline $\begin{array}{l}\text { Herbal plant/ } \\
\text { Standard drug }\end{array}$ & Type of solvent & $\begin{array}{l}\text { Dissolution } \\
\text { percentage (\%) } \\
\text { (Mean } \pm \text { Standard } \\
\text { Deviation) }\end{array}$ \\
\hline Cystone & - & $73.33 \pm 3.82 \mathrm{a}$ \\
Phyllanthus niruri & $n$-hexane & $48.33 \pm 3.82 \mathrm{f}, \mathrm{g}$ \\
& Ethyl acetate & $53.33 \pm 5.20 \mathrm{~d}, \mathrm{e}, \mathrm{f}, \mathrm{g}$ \\
& Methanol & $55.00 \pm 0.00 \mathrm{c}, \mathrm{d}, \mathrm{e}, \mathrm{f}$ \\
& Aqueous & $63.33 \pm 1.44 \mathrm{~b}, \mathrm{c}$ \\
\hline
\end{tabular}

a, b, c,," Values designated with different alphabets are significantly different from each other.

could be carried out effectively with only minimum amount as compared to inhibiting activity (Fig. 1). This is in agreement with similar finding reported by Dwivedi et al. (2016), conclusively revealed that Colocasia leaves show good anti-urolithiatic activity by dissolving the $\mathrm{CaOx}$ crystals even at low amount of phytochemicals.

Dissolution effect of $\boldsymbol{P}$. niruri on calcium oxalate crystals. The result shows in Fig. 2. indicates that aqueous extracts of $P$. niruri was found to be more effective in dissolution of $\mathrm{CaOx}$ with the percentage of $63.33 \% \pm 1.44$. This result was followed by methanol $(55.00 \%)$, ethyl acetate $(53.33 \% \pm 5.20)$ and lastly $n$ hexane extract $(48.33 \% \pm 3.82)$.

Similar to previous studies, aqueous extract of Melia azedarach was studied in male albino Wistar rats against ethylene glycol-induced nephro-lithiasis and this extract has been shown to reduce urinary calcium, oxalate, phosphate and urinary magnesium levels and urinary

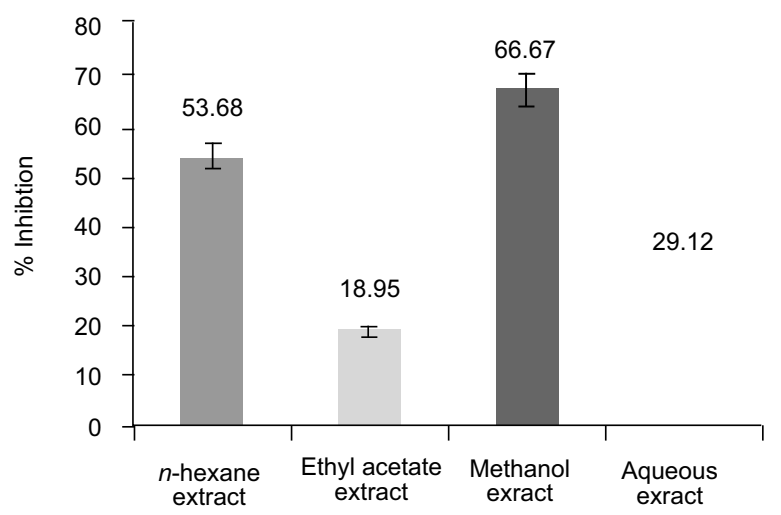

Fig. 1. CaOx inhibition activity of four solvent extracts of P.niruri. 


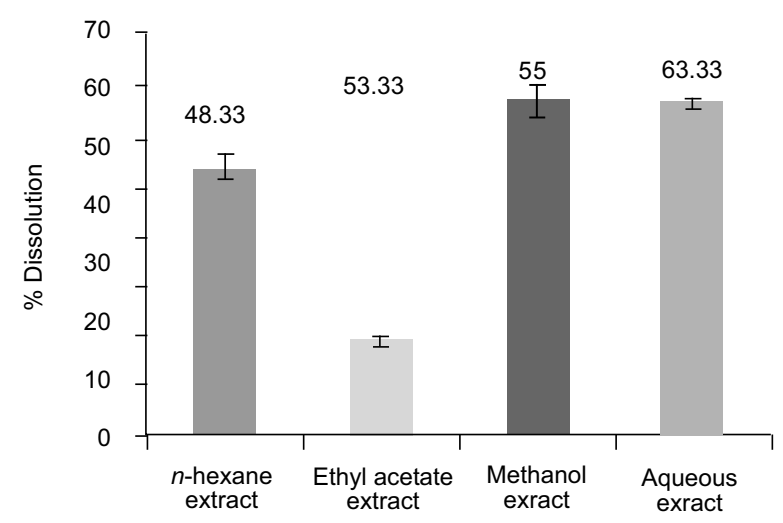

Fig. 2. $\mathrm{CaOx}$ dissolution activity of four solvent extracts of $P$. niruri

volume (Garimella et al., 2001). Moreover, the aqueous extract of C. Spiralis used at a daily dose of 0.25 and $0.5 \mathrm{~g} / \mathrm{Kg}$ for 4 weeks reduced the growth of calcium oxalate calculus in the urinary bladder of rats significantly (Viel et al., 1999). This indicates that the aqueous type of solvent was capable of extracting various plants effectively and can positively act as antiurolithiatic agent.

\section{Conclusion}

Based on result of extraction yield of all extracts, it has been found that the highest percentage was demonstrated of $P$. niruri extract which obtained by using methanol while the lowest yield percentage was obtained by using n-hexane as the extraction solvent. $P$. niruri extract contains different type of phytochemicals depending on the polarity of the solvent used. According to overall result of phytochemical screening, alkaloids are found to be abundant in hexane extracts while most saponins are contained in water extracts. This result might be affected by the polarity of phyto-chemicals and solvents used. Therefore, the ability of all extracts of P. niruri to inhibit and dissolve $\mathrm{CaOx}$ crystal might be beneficial in the treatment of urolithiasis in the future. However, there is a need of further scientific investigation and experimental proofs to support these preliminary findings. Besides, an additional work can also be carried out to isolate, purify and characterize bioactive compounds and to identify their possible mechanism of action.

\section{Acknowledgement}

The research is funded by the Ministry of Education Malaysia under Fundamental Research Grant Scheme
(FRGS) Vot No. 1646 and partially sponsored by Universiti Tun Hussein Onn Malaysia.

Conflict of Interest. The authors declare no conflict of interest.

\section{References}

Ahmad, I., Sabah, A., Anwar, Z., Arif, A., Arsalan, A., Qadeer, K. 2017. Effect of solvent polarity on the extraction of components of pharmaceutical plastic containers. Pakistan Journal of Pharmaceutical Sciences, 30: 247-253.

Azmir, J., Zaidul, I., Rahman, M., Sharif, K., Mohamed, A., Sahena, F., Jahurul, M., Ghafoor, K., Norulaini, N., Omar, A. 2013. Techniques for extraction of bioactive compounds from plant materials: a review. Journal of Food Engineering, 117: 426-436.

Azwanida, N. N.2015. A review on the extraction methods use in medicinal plants, principle, strength and limitation. Medical and Aromatic Plants, 4: 3-8.

Bagalkotkar, G., Sagineedu, S., Saad, M., Stanslas, J. 2006. Phyto-chemicals from Phyllanthus niruri Linn. and their pharmacological properties: a review. Journal of Pharmacy and Pharmacology, 58: 15591570.

Bandar, H., Hijazi, A., Rammal, H., Hachem, A., Saad, Z., Badran, B. 2013. Techniques for the extraction of bio-active compounds from Lebanese urtica Dioica. American Journal of Phytomedicine and Clinical Therapeutics, 1: 507-513.

Bone, K., Mills, S.Y. 2013. Principles and Practice of Phytotherapy, Modern Herbal Medicine, $2^{\text {nd }}$ Edition, pp 1056, Publisher Elsevier Health Sciences, Australia.

Calixto, J.B., Santos, A.R., Filho, V.C., Yunes, R.A. 1998. A review of the plants of the genus Phyllanthus: their chemistry, pharmacology, and therapeutic potential. Medicinal Research Reviews, 18: $225-258$.

Chavan, J., Jagtap, U., Gaikwad, N., Dixit, G., Bapat, V. 2013. Total phenolics, flavonoids and antioxidant activity of Saptarangi (Salacia chinensis L.) fruit pulp. Journal of Plant Biochemistry and Biotechnology, 22: 409-413.

Dailey, A., Vuong, Q.V. 2015. Effect of extraction solvents on recovery of bioactive compounds and antioxidant properties from macadamia (Macadamia tetraphylla) skin waste. Cogent Food and 
Agriculture, 1: 46-56.

Dalimartha, S. 2008. Atlas Tumbuhan Obat Indonesia. (Vol. 2), Niaga Swadaya.

Dwivedi, P., Dwivedi, J., Patel, D., Desai, S., Meshram, D. 2016. Phytochemical analysis and assessment of in vitro urolithiatic activity of colocasia leaves. Journal of Medicinal Plants, 4: 43-47.

Fermeglia, M. 2008. 2 Role of process simulation in extraction technologies for medicinal and aromatic plants. Extraction Technologies for Medicinal and Aromatic Plants. 55-66.

Garimella, T., Jolly, C., Narayanan, S. 2001. In vitro studies on antilithiatic activity of seeds of Dolichos biflorus Linn. and rhizomes of Bergenia ligulata Wall. Phytotherapy Research, 15: 351-355.

Hess, B., Jordi, S., Zipperle, L., Ettinger, E., Giovanoli, R. 2000. Citrate determines calcium oxalate crystallization kinetics and crystal morphologystudies in the presence of Tamm-Horsfall protein of a healthy subject and a severely recurrent calcium stone former. Nephrology Dialysis Transplantation, 15: $366-374$.

Kennedy, J. 2005. Herb and supplement use in the US adult population. Clinical Therapeutics, 27: 18471858.

Kieley, S., Dwivedi, R., Monga, M. 2008. Ayurvedic medicine and renal calculi. Journal of Endourology, 22: 1613-1616.

Kotze, M., Eloff, J., Houghton, P. 2002. Extraction of antibacterial compounds from Combretum microphyllum (Combretaceae). South African Journal of Botany, 68: 62-67.

KV, T., George, S., Balachandran, I. 2014. Phenolic characterisation of selected Salacia species using LC-ESI-MS/MS analysis. Natural Product Research, 28: 1021-1024.

Malini, M., Lenin, M., Varalakshmi, P. 2000. Protective effect of triterpenes on calcium oxalate crystalinduced peroxidative changes in experimental urolithiasis. Pharmacological Research, 41: 413418.

Narendra, K., Swathi, J., Sowjanya, K., Satya, A.K. 2012. Phyllanthus niruri: a review on its ethno botanical, phytochemical and pharmacological profile. Journal of Pharmacy Resesrch, 5: 46814691.

Pauzi, A.N., Muhammad, N., Sairi, N.H., Putra, T.N.M.T., Gul, M.T., Rahim, N.F.A., Marzuki,
N.A.S., Bakar, M.F.A., Talip, B.A., Abdullah, N. 2018. The effect of different solvent extraction towards antiurolithiatic properties of Euphorbhia hirta and Orthosiphon stamineus. In: International Conference on Biodiversity, UTHM Pagoh Malaysia.

Ram, J., Moteriya, P., Chanda, S. 2015. An overview of some promising medicinal plants with in vitro anti-urolithiatic activity. Journal of Pharmacy, 5: 23-28.

Rebey, I.B., Bourgou, S., Debez, I.B.S., Karoui, I.J., Sellami, I.H., Msaada, K., Limam, F., Marzouk, B. 2012. Effects of extraction solvents and provenances on phenolic contents and antioxidant activities of cumin (Cuminum cyminum L.) seeds. Food and Bioprocess Technology, 5: 2827-2836.

Sharma, D., Dey, Y.N., Sikarwar, I., Sijoria, R., Wanjari, M.M., Jadhav, A.D. 2016. In vitro study of aqueous leaf extract of Chenopodium album for inhibition of calcium oxalate and brushite crystallization. Egyptian Journal of Basic and Applied Sciences, 3: 164-171.

Singanallur, R.R., Doraiswamy, R., Yadav, H.M. 2017. Antiurolithiatic activity of aqueous bark extract of Crateva magna Lour. (DC). International Journal of Research in Ayurveda and Pharmacy, 8: 271-278.

Subramoniam, A. 2014. Present scenario, challenges and future perspectives in plant based medicine development. Ann. Phytomed, 3: 31-36.

Suleiman, M.M., McGaw, L.J., Naidoo, V., Eloff, J.N. 2010. Evaluation of several tree species for activity against the animal fungal pathogen Aspergillus fumigatus. South African Journal of Botany, 76: 64-71.

Tiwari, P., Kumar, B., Kaur, M., Kaur, G., Kaur, H. 2011. Phytochemical screening and extraction: a review. Internationale Pharmaceutica Sciencia, 1: 98-106.

Viel, T.A., Domingos, C.D., da Silva Monteiro, A.P., Lima-Landman, M.T.R., Lapa, A.J., Souccar, C. 1999. Evaluation of the antiurolithiatic activity of the extract of Costus spiralis Roscoe in rats. Journal of Ethno-pharmacology, 66: 193-198.

Wang, M., Cheng, H., Li, Y., Meng, L., Zhao, G., Mai, K. 1995. Herbs of the genus Phyllanthus in the treatment of chronic hepatitis B: observations with three preparations from different geographic sites. The Journal of Laboratory and Clinical Medicine, 126: $350-352$. 